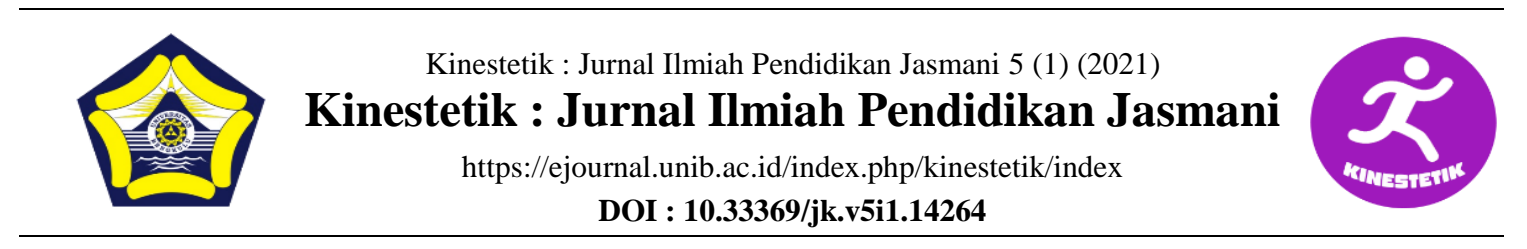

\title{
EFFECTIVENESS OF ONLINE LEARNING AND PHYSICAL ACTIVITIES STUDY IN PHYSICAL EDUCATION DURING PANDEMIC COVID 19
}

\author{
Rohmad Apriyanto ${ }^{1 *}$, Adi $\mathrm{S}^{2}$ \\ ${ }^{12}$ Physical Education, Health and Recreation Study Program, Teaching Faculty of Education, \\ Universitas Nahdlatul Ulama Sunan Giri Bojonegoro, Jawa Timur, Indonesia
}

Article Info

Article History :

Received : January 2021

Revised : February 2021

Accepted : March 2021

Available online : March 2021

Keywords:

Education, Effectiveness, Online Learning, Physical

\section{Abstract}

This study aims to determine the effectiveness of learning and physical activity in Physical Education with online media during the covid 19. Pandemic is a descriptive quantitative research about learning conditions using online learning. The population in this study SMA Plus Alfatimah students who carry out online learning. The samples in this study were Class X, XI and XII sample using total sampling. There are 346 respondes. The data collection instrument used online learning questionnaire used google form. Data analysis used descriptive statistics. The study showed that, students assessed physical education learning with online learning is very effective (8.3\%) effective (36.9\%) normal (40.2\%) although there are also students who think ineffective online learning (11.6) very ineffective (2.9\%). Result research on physical activity during the covid pandemic 19 (4.6) students do very high physical activity, (19.9\%) in the high category. (69.7\%) medium category and (5.8\%) in low category. Types of sports activities that are conducted by students $(65.1 \%)$ ) health sports, $(23.2 \%)$ recreational sports, $(9.1 \%)$ sports education, $(2.6 \%)$ accomplishment sports. The habits of students has changes because this pandemic. Students are more often help parents activities at home. Habit changes due to during the pandemic, students do not live in school dormitories but in school respective homes. During online activities most of the students do not experienced significant impacts both physically and psychologically. Learners tend to be more interested in a mix of learning both online and offline. Students also have a deep level of interest use of certain online media used by educators. Learners also have an interest in the approach to using online learning methods.

\begin{tabular}{llr}
\hline Corresponding address & : Jl. Jendral Ahmad Yani No.10, Jambean, & ISSN 2685-6514 (Online) \\
& Sukorejo, Kab. Bojonegoro, Jawa Timur & ISSN 2477-331X (Print) \\
*Corresponding email & $:$ rohmadapriyanto87@gmail.com, &
\end{tabular}




\section{INTRODUCTION}

Corona is an infectious disease caused by the SARS-CoV-2 virus (Gorbalenya, 2020). Difficulty breathing, dry cough and fever are usually symptoms experienced by sufferers (Fajar, 2020). Corona disease is a newly discovered infectious disease. Patients who are infected have mild to moderate respiratory symptoms. Currently, corona also affects teaching and learning activities within the Ministry of Education and Culture (Kemendikbud). Online learning is becoming popular these days.

The government takes preventive action by providing policies for the education sector, namely for students to replace face-to-face learning activities with online learning to prevent the gathering of many people in one room, this policy was taken by the government because of the obligation of students to continue studying. The impact of the imposition of social distancing which is enforced makes learning activities more at home, so that more activities are carried out from home. physical activities carried out daily to carry out activities become routine activities.

Doing simple physical activity can be used to survive (Cheng et al., 2018; Engeseth et al., 2018; Tiberi \& Piepoli, 2019). The amount of free time and not doing physical activity have a negative correlation with the risk of cardiovascular death (Cheng et al., 2018). Physical fitness not only reduces the risk of death from cardiovascular disease, but also possibly by doing regular physical exercise (Engeseth et al., 2018). Limited physical activity or, even more worryingly, the inability to walk out of the house regularly as a consequence of strict quarantine, can be associated with the risk of many disorders and diseases such as diabetes, cancer, osteoporosis and cardiovascular disease (Castrogiovanni et al., 2016; Sanchis-Gomar et al., 2014). A decrease in physical activity can also affect a person's mental health, which may be experienced as unpleasant emotions such as sadness, anger and frustration (Brooks et al., 2020) . Physical activity can be positively correlated with a pandemic state. Simple physical activity can reduce the negative effects of strict quarantine.

(Luthra \& Mackenzie, 2020), technology is an important sector in educating future generations. According to (Castro \& Tumibay, 2019), online-based learning provides several advantages such as flexible access and content. It becomes an important thing for an educator to test and consider the effectiveness of online learning he does (Radha et al., 2020) Elearning has become very popular among students around the world, especially during the lockdown period due to the Corona Virus Disease 2019 pandemic.

\section{Problem statement}

This study aims to determine how the effectiveness of learning and physical activity in PE subjects using online media during the COVID-19 pandemic.

\section{METHODS}

This study uses descriptive quantitative methods to determine the effectiveness of learning and physical activity in PE subjects using online media during the COVID-19 pandemic. The population in this study were all students 
of SMA PLUS ALFATIMAH who carried out online learning. The samples in this study were Class X, XI and XII. The sampling technique used total sampling. The data collection instrument used an online learning questionnaire containing questions that were shared using google form. Data analysis using descriptive statistics. Al-Fatimah School is a school that contains female students, there are no male students in this school. All respondents in this study 346 were women.

\section{RESULT}

\section{PE Online Learning}

a. Learning that Students Interested School with a boarding character as a place to live and develop one's abilities. Practicing independence in a hostel environment forms a religious personal character. Based on the study in terms of student interest in receiving physical education learning materials for sports and health used face-to-face models before and during pandemic. $40.1 \%$ showed that students were more interested in combining online and face-to-face learning, $35 \%$ of students were interested in online learning, and $24.9 \%$ were interested in face-to-face learning.

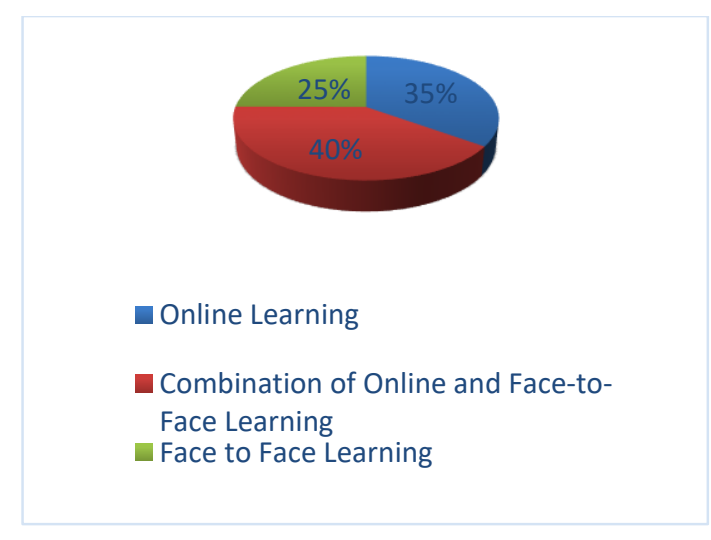

Figure 1. The preferred online learning model b. Online Learning Media that Students Interested

Results related to the use of applications or online learning media in PE subjects. To support the learning material achievements, many online media can be used. The results of the research on student interest were $43.2 \%$ WhatsApp group, $34.4 \%$ Google Classroom, $11.6 \%$ Zoom, 6.2\% Instagram, 3.7 YouTube, $0.8 \%$ Microsoft Teams.

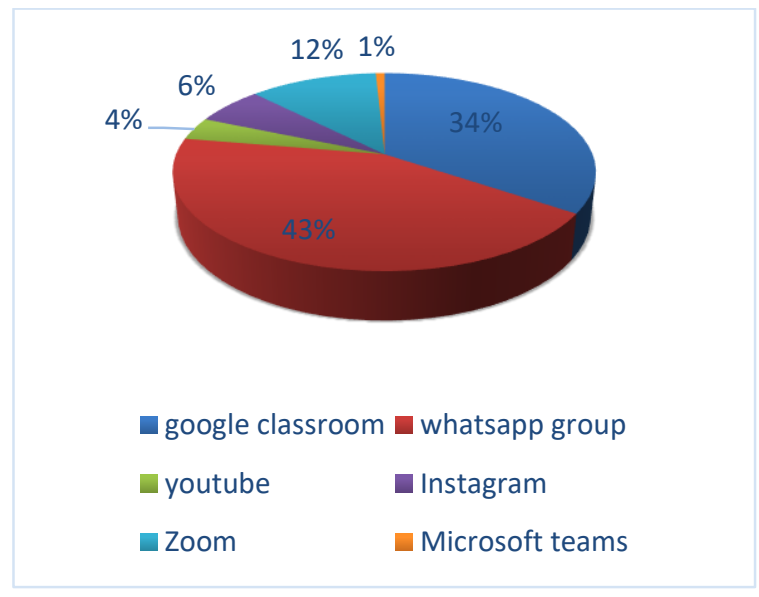

Figure 2. Learning media of interest in online learning

c. Online Learning Methods That Are Interested Students

Research results online learning methods that are of interest to the subjects of PE $46.9 \%$ Teacher speakers, $12 \%$ individual assignments, $11.6 \%$ videos, $11.2 \%$ group assignments, $10 \%$ discussion, $8,3 \%$ quiz.

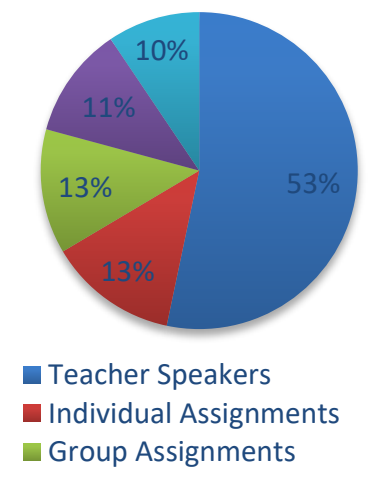

Figure 3. Learning methods that are of interest to students in online learning. 


\section{d. Problems Facing Students}

Results of the research on the obstacles faced by students in the online learning process $30.7 \%$ more tasks, $24.9 \%$ unstable internet networks, $23.7 \%$ limited internet quota, $15.4 \%$ difficult to focus, $5.4 \%$ applications complicated.

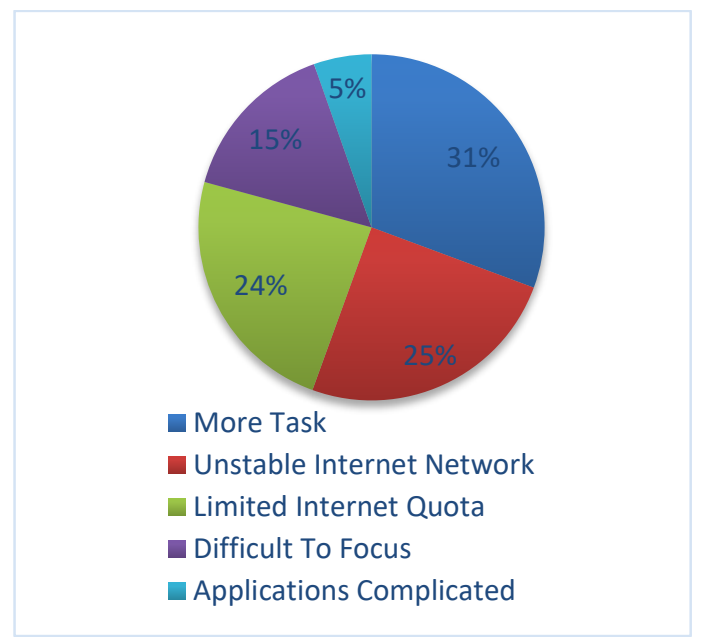

Figure 4. Problems faced by students during online learning

e. Effectiveness of online learning

The results were $40.2 \%$ mediocre, $37 \%$ Effective, $11.6 \%$ ineffective, $8.3 \%$ very effective, $2.9 \%$ very ineffective.

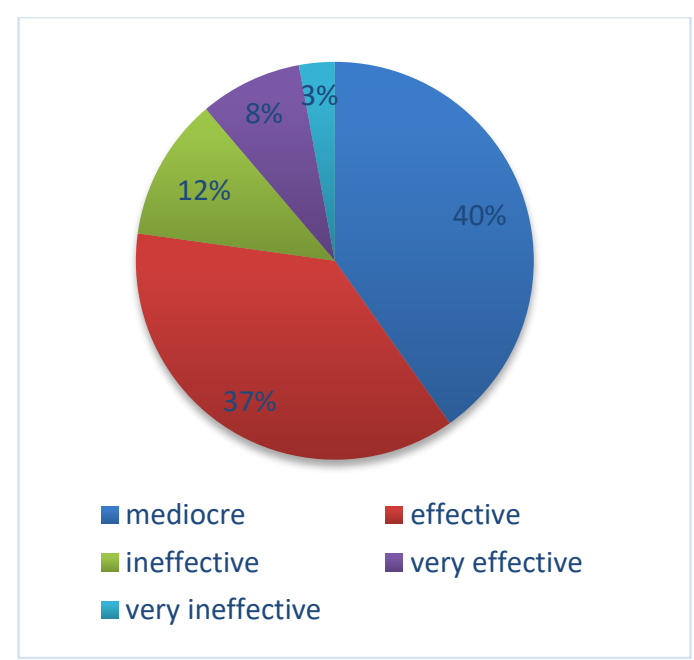

Figure 5. Effectiveness of online learning in $\mathrm{PE}$ during the pandemic

\section{Physical Activity}

a. Physical Activity Intensity

The results of research on the intensity of physical activity during online learning outside school learning hours. The results showed $69.7 \%$ medium category $19.9 \%$ high category, $5.8 \%$ low category, $4.6 \%$ very high category.

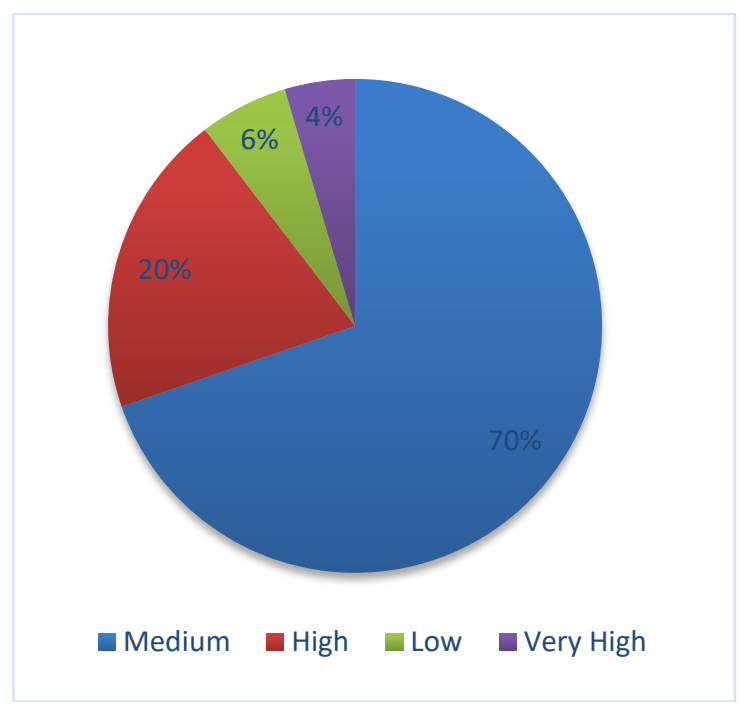

Figure 6. The intensity of physical activity during the pandemic

b. Type of sports activity

The results of the research on the types of sports activities that were of interest during the pandemic were $65.1 \%$ health sports, $23.2 \%$ recreational sports, $9.1 \%$ educational sports, and $2.6 \%$ pro sports

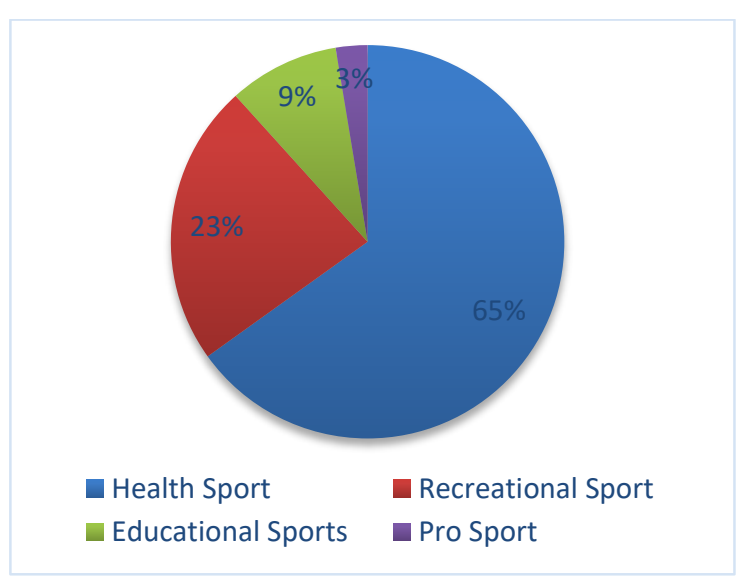

Figure 7. Types of sports activities that are often done during a pandemic 


\section{DISCUSSION}

Online learning is becoming popular these days because everything has to be at a distance. Besides preventing the transmission of the corona virus. Whatssapgrup and googleform are platforms that are often used because students are very familiar with them. In addition, the platform is easy to use even in low signal conditions. The lecture teacher method is an interesting method to use during this pandemic. This is because teachers are the primary source of information. In physical education learning, teachers with the lecture method can make students move. The first problem with distance learning is that there are more assignments. Besides that, a stable internet connection also makes it difficult. The effectiveness of this pandemic study is high and some consider it normal.

There is a lot of research that shows the effectiveness of online learning. First, research conducted by (Navarro \& Shoemaker, 2000), this study states that students in online learning have the same or even better learning outcomes than students who learn in the traditional way. This fact is apart from students who are very satisfied with online learning itself. Second, (Rovai \& Jordan, 2004) which examines the meaning of a traditionally packaged and mixed format classroom. Students in mixed form have a strong sense of community. Methodological studies carried out by (Bowen et al., 2014), have been randomly assigned to traditional control groups. Meanwhile, the experimental group was conducted in an online interactive learning format. Online learning is done face to face once a week. Where meetings are spent more on online work. From the research results it was found that the two lessons were the same in terms of results. Repair costs and increase student productivity over time for online learning. From this online learning, it is hoped that some new software for online learning can be canceled which can be developed and tested continuously. It is hoped that students will be more effective and efficient in their learning. Online learning if it is well developed and carried out "Fit \& Proper Test" will make learning colorful. Students' interest in new things in this era will make it easier for teachers to achieve their learning goals.

Physical activity during this pandemic is included in the medium category. The limited space for movement during this pandemic made students limit their physical activities. But on the other hand, students do health sports more often. The level of physical activity has a big impact on health. One-third of students who have a moderately high level of physical activity in high school become inactive when transitioning to university life (Simona et al., 2015). On the other hand, within the scope of school, students receive Physical Education subjects that have a positive impact on an active lifestyle. Physical Education has the advantage of making a person's style active which increases physical activity. (Bailey et al., 2009). Although the results of the study (Olivares et al., 2015) state that the influence of parents is more relevant than the influence of physical education teachers to promote physical activity in adolescents, regardless of age, gender and physical condition.

Limiting the rapid spread of the COVID-19 is a priority program because it relates to public health. Some recommendations for activities that someone should do in maintaining health, one of which is physical activity. With good physical activity, it is expected that immunity will increase (Chen et al., 2020; Hall et al., 2020). Maintaining psychophysical health in locked situations is of utmost importance, and special attention should be paid to the elderly population and children. As a person gets older it 
makes it more difficult to restore proper musculoskeletal function. Teens and children have a higher activity level than adults. Adults find it difficult to achieve adequate physical activity during quarantine and at home.(Sheldrick et al., 2019). Physical and social environmental factors that work in the space of the house do have an important effect on physical behavior and activity, especially for the child population (Puggina et al., 2016). One teenager observed an increased risk of increasing total screen use. The screen in question is the total duration used to play cellphones, computers, Television and Video Games. This is a finding that must be followed up. The tendency to watch the screen longer can lead to someone having low physical activity.

\section{CONCLUSION}

The learning media used by educators in delivering material during a pandemic is very important in supporting learning achievement. The subjects of PE are dominated by the psychomotor domain. The psychomotor domain is related to movement skills and the main goal, namely physical fitness. The results showed that the most effective and preferred media for students was the $43.2 \%$ whatapp group where the whatapp group media made it easier for students to follow online learning and collect tasks in the form of videos. The learning method most interested in students during online learning is the $47 \%$ lecture method. The learning model that students are interested in is $40.1 \%$ choosing a mix of online and offline learning. The effectiveness of online learning during the pandemic $37 \%$ of students rated it as effective. The results of the research on the physical activity of students during the pandemic period were $69.7 \%$ in the moderate category. Types of sports activities that are often done by students during the pandemic, $65.1 \%$ of students do health sports.

\section{REFERENCES}

Bailey, R., Richard, Armour, K., Kirk, D., Jess, M., Pickup, I., \& Sandford, R. (2009). The educational benefits claimed for physical education and school sport: An academic review. Research Papers in Education, 24. https://doi.org/10.1080/0267152070180 9817

Bowen, W., Chingos, M., Lack, K., \& Nygren, T. (2014). Interactive Learning Online at Public Universities: Evidence from a Six-Campus Randomized Trial. Journal of Policy Analysis and Management, 33. https://doi.org/10.1002/pam.21728

Brooks, S., Webster, R., Smith, L., Woodland, L., Wessely, S., Greenberg, N., \& Rubin, G. (2020). The psychological impact of quarantine and how to reduce it: rapid review of the evidence. The Lancet, 395. https://doi.org/10.1016/S01406736(20)30460-8

Castro, M. D., \& Tumibay, G. (2019). A literature review: efficacy of online learning courses for higher education institution using meta-analysis. Education and Information Technologies, 1-19. https://doi.org/10.1007/s10639-01910027-z

Castrogiovanni, P., Trovato, F., Szychlinska, M., Nsir, H., Imbesi, R., \& Musumeci, G. (2016). The importance of physical activity in osteoporosis. From the molecular pathways to the clinical evidence. Histology and Histopathology, $31, \quad 11793$. https://doi.org/10.14670/HH-11-793

Chen, P., Mao, L., Nassis, G. P., Harmer, P., Ainsworth, B. E., \& Li, F. (2020). Wuhan coronavirus (2019-nCoV): The need to maintain regular physical activity while taking precautions. Journal of Sport and Health Science, 9(2), 103-104. https://doi.org/10.1016/j.jshs.2020.02.0 01 
Cheng, W., Zhang, Z., Cheng, W., Yang, C., Diao, L., \& Liu, W. (2018). Associations of leisure-time physical activity with cardiovascular mortality: A systematic review and meta-analysis of 44 prospective cohort studies. European Journal of Preventive Cardiology, 25(17), 1864-1872. https://doi.org/10.1177/2047487318795 194

Engeseth, K., Prestgaard, E., Mariampillai, J., Grundvold, I., Liestol, K., Kjeldsen, S., Bodegard, J., Erikssen, J., Gjesdal, K., \& Skretteberg, P. (2018). Physical fitness is a modifiable predictor of early cardiovascular death: A 35-year followup study of 2014 healthy middle-aged men. European Journal of Preventive Cardiology, 25, 204748731879345. https://doi.org/10.1177/2047487318793 459

Fajar, M. (2020). Estimation Of Covid-19 Reproductive Number Case of Indonesia (Estimasi Angka Reproduksi Novel Coronavirus (COVID-19) Kasus Indonesia).

https://doi.org/10.13140/RG.2.2.32287. 92328

Gorbalenya, A. (2020). Severe acute respiratory syndrome-related coronavirus - The species and its viruses, a statement of the Coronavirus Study

Group. https://doi.org/10.1101/2020.02.07.937 862

Hall, G., Laddu, D., Phillips, S., Lavie, C., \& Arena, R. (2020). A tale of two pandemics: How will COVID-19 and global trends in physical inactivity and sedentary behavior affect one another? Progress in Cardiovascular Diseases. https://doi.org/10.1016/j.pcad.2020.04.0 05

Luthra, \& Mackenzie. (2020). 4 Ways Covid19 Could Change How We Educate Future Generations.

Olivares, P., Cossio-Bolaños, M., GomezCampos, R., Almonacid Fierro, A., \& García, J. (2015). Influence of parents and physical education teachers in adolescent physical activity. International Journal of Clinical and Health Psychology, 380. https://doi.org/10.1016/j.ijchp.2015.01. 002

Puggina, A., Aleksovska, K., Carlin, A., Condello, G., Cortis, C., Jaeschke, L., Kennedy, A., MacDonncha, C., Capranica, L., Boccia, S., \& consortium, on. (2016). "Determinants of Diet and Physical Activity" (DEDIPAC): an umbrella systematic literature review: Anna Puggina. In European Journal of Public Health (Vol. 26). https://doi.org/10.1093/eurpub/ckw165. 022

Radha, R., Mahalakshmi, K., Kumar, V. S., \& Saravanakumar, A. R. (2020). ELearning during Lockdown of Covid-19 Pandemic: A Global Perspective. International Journal of Control and Automation, 13(4), 1088-1099.

Sanchis-Gomar, F., Lucia, A., Yvert, T., RuizCasado, A., Pareja-Galeano, H., SantosLozano, A., Fiuza-Luces, C., Garatachea, N., Lippi, G., Bouchard, C., \& Berger, N. (2014). Physical Inactivity And Low Fitness Deserve More Attention To Alter Cancer Risk And Prognosis. Cancer Prevention Research, 8. $\quad$ https://doi.org/10.1158/19406207.CAPR-14-0320

Sheldrick, M., Maitland, C., Mackintosh, K., Rosenberg, M., Griffiths, L., Fry, R., \& Stratton, G. (2019). Associations between the Home Physical Environment and Children's HomeBased Physical Activity and Sitting. International Journal of Environmental Research and Public Health, 16, 4178. https://doi.org/10.3390/ijerph16214178

Simona, F., Radu, L., \& Vanvu, G. I. (2015). The Level of Physical Activity of University Students. Procedia - Social and Behavioral Sciences, 197, 14541457.https://doi.org/10.1016/j.sbspro.20 15.07.094

Tiberi, M., \& Piepoli, M. F. (2019). Regular physical activity only associated with low sedentary time increases survival in post myocardial infarction patient. European Journal of Preventive Cardiology, 26(1), 94-96. https://doi.org/10.1177/2047487318811 180 